HISTÓRIA dA UnIÃo SoviÉTICA

Lincoln Secco

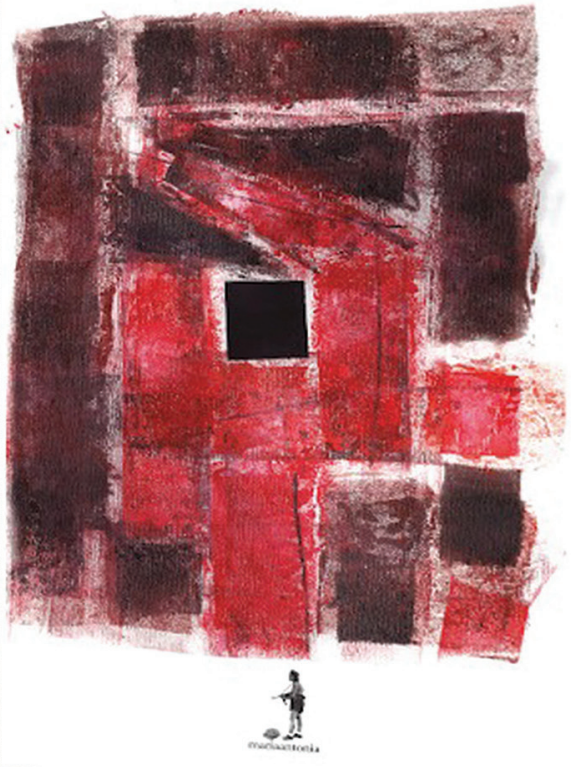

\title{
A União Soviética e suas contradições
}

\section{Deise Rosalio Silva}

História da União Soviética: uma introdução, de Lincoln Secco,

São Paulo, Maria Antonia Edições, 2020, 159 p. 


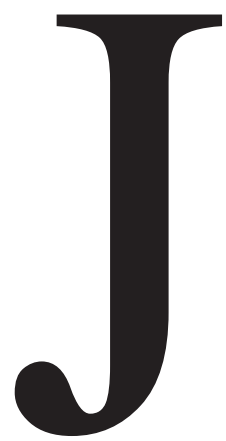

á diria Marx, em $O 18$ de Brumário de Luís Bonaparte, que "os homens fazem sua própria história, mas não a fazem como querem, não a fazem sob circunstâncias de sua escolha". Se essa máxima expressa uma exigência indubitável da própria materialidade humana, revisitar o passado é sempre um exercício de recomposição das peças que possibilitaram uma determinada construção, não para movê-las, mas para nos lermos no mundo compreendendo melhor o caminho, na ânsia de termos maiores condições de pisar nele e compor as tessituras que virão. Nesse sentido, a obra História da União Soviética, de Lincoln Secco, que vem a público agora pela Maria Antonia Edições, é um desnovelar primoroso do emaranhado de um dos feitos mais marcantes, definidores e ressoantes do século XX: a União Soviética.

Organizada em sete capítulos, Lincoln desenreda argutamente as permanências e rupturas, sem se furtar de avultar as antinomias que possibilitaram a edificação, a prossecução e a ruína do Estado soviético. E revela já de cara a sua não pretensa neutralidade, mas o compromisso em não circunscrever a obra no arcabouço da sua posição.

No Capítulo 1, percorre desde a Revolução Russa de 1917, destrinchando os acontecimentos, a participação dos trabalhadores nas greves, problematizando o caráter da revolução, o papel indispensável de Lênin nessa trilha e o debate ao redor dos episódios. No Capítulo 2, se debruça sobre a guerra civil, revelando, inclusive, as fake news e os contrastes que marcaram a odisseia bolchevique. O Capítulo 3, dedicado à análise do socialismo em um só país, apura o despontar imprevisível de um sujeito como Stalin, que era "seguramente o menos reconhecido intelectual e politicamente" (p. 38) e todo o delinear dessa passagem do leninismo ao stalinismo, marcando distinções, a disciplina,

DEISE ROSALIO SILVA é professora

da Faculdade de Educação da Universidade Federal de Minas Gerais. 
o recuo, a censura à arte, já antecipando como "sem uma expressão cultural nenhum regime perdura por si mesmo" (p. 43).

No Capítulo 4, especificamente destinado ao stalinismo, aprofunda a abordagem sobre o regime, expondo suas veias contraditórias: de um lado, por exemplo, uma notável capacidade de trabalho e reconhecimento da importância social das mulheres, de outro, a repressão e o terror em massa, revelando o quanto o stalinismo se movimentava nos paradoxos. "No interior, a máxima repressão. No exterior, a busca do consenso" (p. 66). No entanto, adverte que as responsabilidades eram coletivas, não apenas o medo, mas a covardia, a cumplicidade e a isenção ancoravam a política de Stalin: conjugador de "grande líder" e "déspota assassino" (p. 69). Esclarece também o auge do governo, a relação com a guerra e os limites do processo de desestalinização. O Capítulo 5 versa sobre a Internacional, do seu surgimento ao papel que adquire na arena de edificação de um regime imperfeito, mas que "parecia a única alternativa a um capitalismo em crise" (p. 77) e a necessidade da luta antifascista. Traz inúmeros dados sobre todo esse processo, descortinando do crescimento ao declínio dos partidos comunistas.

O Capítulo 6 trata das revoluções de 1989, as reformas consequentes, perpassa as particularidades das revoltas em cada país do bloco, demarcando que a restauração capitalista suplanta de tal forma a perspectiva socialista que o abate causado por duas décadas neoliberais abre espaço ao neofascismo. Por fim, o Capítulo 7 coroa a análise sobre o fim da União Soviética, desmistificando a falácia do fracasso econômico, o êxito na corrida espacial, explorando toda a trajetória, desde a Nova Política Econômica
(NEP), a coletivização, apresentando dados sobre o crescimento robusto e a melhora do padrão social da população, sem negligenciar a exploração da força de trabalho e que as relações de produção nunca foram alteradas. Mas esmiuça a complexidade e o impacto que a Guerra Fria trazia ao exigir do regime, que tinha uma lógica econômica distinta, um grande esforço na corrida armamentista que não lhe gerava a demanda agregada do capitalismo.

O autor sobreleva responsavelmente a multiplicidade de fatores que culminam na dissolução do regime, enfatizando o quanto "a luta de classes é a chave histórica para se entender o fim do socialismo real" (p. 124). A saída dos comunistas do bloco soviético do poder não foi resultante de uma deposição à força, mas da passagem de ditos comunistas, reais burocratas, a acionistas. Finaliza brilhantemente nos provocando a ponderar, entre profundos erros e acertos, a inegável melhor condição da classe trabalhadora mundial durante esse período.

Talvez justamente por ser fruto de quase 20 anos de diálogo com os alunos, essa obra dialogue tanto, de maneira clara e cuidadosa, e abarque aspectos em geral negligenciados na historiografia do assunto, como homossexualidade, ecologia e gênero.

Com um olhar diligente e rigoroso com os dados históricos, Lincoln Secco constrói um texto afiado, entremeado com expressões atuais que aproximam o leitor, ampliam o sentido sobre os acontecimentos e nos convidam a avivar também a leitura do presente. Denotando generosamente toda a dialética das peripécias, seus personagens e engrenagens, o autor desnuda as contradições dessa experiência política singular da história da humanidade. 